\title{
Production, purification, sequencing and activity spectra of mutacins D-123.1 and F-59.1
}

Guillaume G Nicolas ${ }^{1,2^{*}}$, Gisèle LaPointe ${ }^{2}$ and Marc C Lavoie ${ }^{3,4}$

\begin{abstract}
Background: The increase in bacterial resistance to antibiotics impels the development of new anti-bacterial substances. Mutacins (bacteriocins) are small antibacterial peptides produced by Streptococcus mutans showing activity against bacterial pathogens. The objective of the study was to produce and characterise additional mutacins in order to find new useful antibacterial substances.

Results: Mutacin F-59.1 was produced in liquid media by S. mutans 59.1 while production of mutacin D-123.1 by S. mutans 123.1 was obtained in semi-solid media. Mutacins were purified by hydrophobic chromatography. The amino acid sequences of the mutacins were obtained by Edman degradation and their molecular mass was determined by mass spectrometry. Mutacin F-59.1 consists of 25 amino acids, containing the YGNGV consensus sequence of pediocin-like bacteriocins with a molecular mass calculated at 2719 Da. Mutacin D-123.1 has an identical molecular mass (2364 Da) with the same first 9 amino acids as mutacin I. Mutacins D-123.1 and F-59.1 have wide activity spectra inhibiting human and food-borne pathogens. The lantibiotic mutacin D-123.1 possesses a broader activity spectrum than mutacin F-59.1 against the bacterial strains tested.

Conclusion: Mutacin F-59.1 is the first pediocin-like bacteriocin identified and characterised that is produced by Streptococcus mutans. Mutacin D-123.1 appears to be identical to mutacin I previously identified in different strains of S. mutans.
\end{abstract}

Keywords: bacteriocin lantibiotic, mutacin, pediocin, Streptococcus mutans

\section{Background}

The excessive and often inappropriate use of antibiotics leads to a continuous increase and spread of antibiotic resistance among bacteria, thus making it imperative to discover and carefully use new antibacterial substances [1]. Bacteriocins are bacterial ribosomally synthesised proteinaceous substances with strong antibacterial activity, excellent structural stability, low immunogenicity, while resistance does not develop frequently [2-4]. One general mechanism of action of bacteriocins involves pore formation in target cells leading to the leakage of small molecules and cell death $[4,5]$. Bacteriocins from Gram positive bacteria can be grouped into three classes: class I which includes lantibiotics containing post-translationally modified amino acids such as lanthionine and dehydrated amino acids, class II non-

\footnotetext{
* Correspondence: guiOme.nicolas@gmail.com

'Département de Biochimie Microbiologie et Bioinformatique, Faculté des Sciences et Génie, Université Laval, Québec (Québec), G1K 7P4, Canada Full list of author information is available at the end of the article
}

lantibiotics, containing only common amino acids and class III containing bacteriocins with higher molecular mass (> $10 \mathrm{kDa}$ ) [2,4]. Lantibiotics (class I) are divided into type A (elongated linear peptides) and type B (globular peptides) [5]. Class II is subdivided into three subclasses, namely, class IIa (pediocin-like bacteriocins), class IIb (two-peptide bacteriocins) and class IIc (other one-peptide bacteriocins) [2]. The biosynthesis of bacteriocins requires the translation of the prepeptide, posttranslational modifications such as dehydration and cyclisation reactions to form the thioether bridges in lantibiotics and cleavage of the leader peptide during transport outside of the cell $[2,4]$. Streptococcus mutans, a human indigenous oral bacterial species, is known to produce bacteriocins named mutacins [6]. It is believed that production of such mutacins may confer to $S$. mutans an advantage against competitive species living in the same niche [6]. To date, mutacins from class I and class II have been purified and characterised: the mono-peptide lantibiotic (mutacin B-Ny266), the di-
C Biomed Central

(C) 2011 Nicolas et al; licensee BioMed Central Ltd. This is an Open Access article distributed under the terms of the Creative Commons Attribution License (http://creativecommons.org/licenses/by/2.0), which permits unrestricted use, distribution, and reproduction in any medium, provided the original work is properly cited. 
peptide lantibiotic (mutacin GS-5), the mono-peptide non-lantibiotic (mutacin N) and the di-peptide non-lantibiotic (mutacin IV) [for review see reference 6 and references therein]. Production of more than one mutacin by a given strain has been experimentally demonstrated for several strains and is also predicted by bioinformatic analysis of sequenced strain genomes [6]. Mutacin-producing strains and some of their purified peptides have shown activity against Gram positive and some Gram negative bacteria in vitro and in vivo [7-9]. Because of their biochemical diversity and activity spectra, many applications can be expected for mutacins as antibiotics or food preservatives $[3,10]$.

The main objective of our research is to further characterise mutacins to uncover new useful antibacterial substances active against bacterial pathogens. We previously classified 86 mutacin-producing strains into 24 groups (designated $\mathrm{A}$ to $\mathrm{X}$ ) and subsequently seven clusters of activity were defined from the 24 type strains. This grouping was based only on their activity spectra towards other mutacinogenic strains and against various bacterial species including pathogens $[8,11]$. S. mutans 59.1 and 123.1 were clearly distinct in their activity spectra and the mutacins produced by these strains were not genetically related to the well known lantibiotics (nisin, gallidermin, epidermin, subtilin) nor to previously well characterised mutacins (B-Ny266, B-JH1140 (mutacin III), J-T8 (mutacin II), H-29B) by using specific molecular probes $[8,12]$. We present here results on the production, purification and characterisation of mutacins F-59.1 and D-123.1.

\section{Results}

Mutacin F-59.1 was produced in SWP and the activity was measured as $400 \mathrm{AU} / \mathrm{mL}$ while production of mutacin D-123.1 was achieved in semi-solid medium by using tryptic soy with yeast extract containing agarose. Activity of the crude mutacin D-123.1 preparation was measured to be $200 \mathrm{AU} / \mathrm{mL}$.

Mutacins D-123.1 and F-59.1 were purified by successive steps of hydrophobic chromatography. Active fractions of mutacin F-59.1 purification were recovered with an elution gradient of $50 \%-60 \%$ methanol in $10 \mathrm{mM}$ $\mathrm{HCl}$ (Figure 1) and those of mutacin D-123.1 with a $60 \%-70 \%$ gradient (Figure 2). The final specific activities were $3.2 \times 10^{5} \mathrm{AU} / \mathrm{mg}$ for the purified mutacin F-59.1 and of $1.6 \times 10^{5} \mathrm{AU} / \mathrm{mg}$ for the purified mutacin D123.1 (Table 1).

A total of 25 amino acids were sequenced for mutacin F-59.1 and its identity with pediocin-like bacteriocins was confirmed by multiple alignment (Figure 3 ). The sequence revealed high levels of similarity to class IIa bacteriocins with the presence of the five residues of the common consensus sequence-YGNGV-and the two conserved cysteine residues at positions 9 and 14. The substitution of unidentified amino acids (annotated X) in

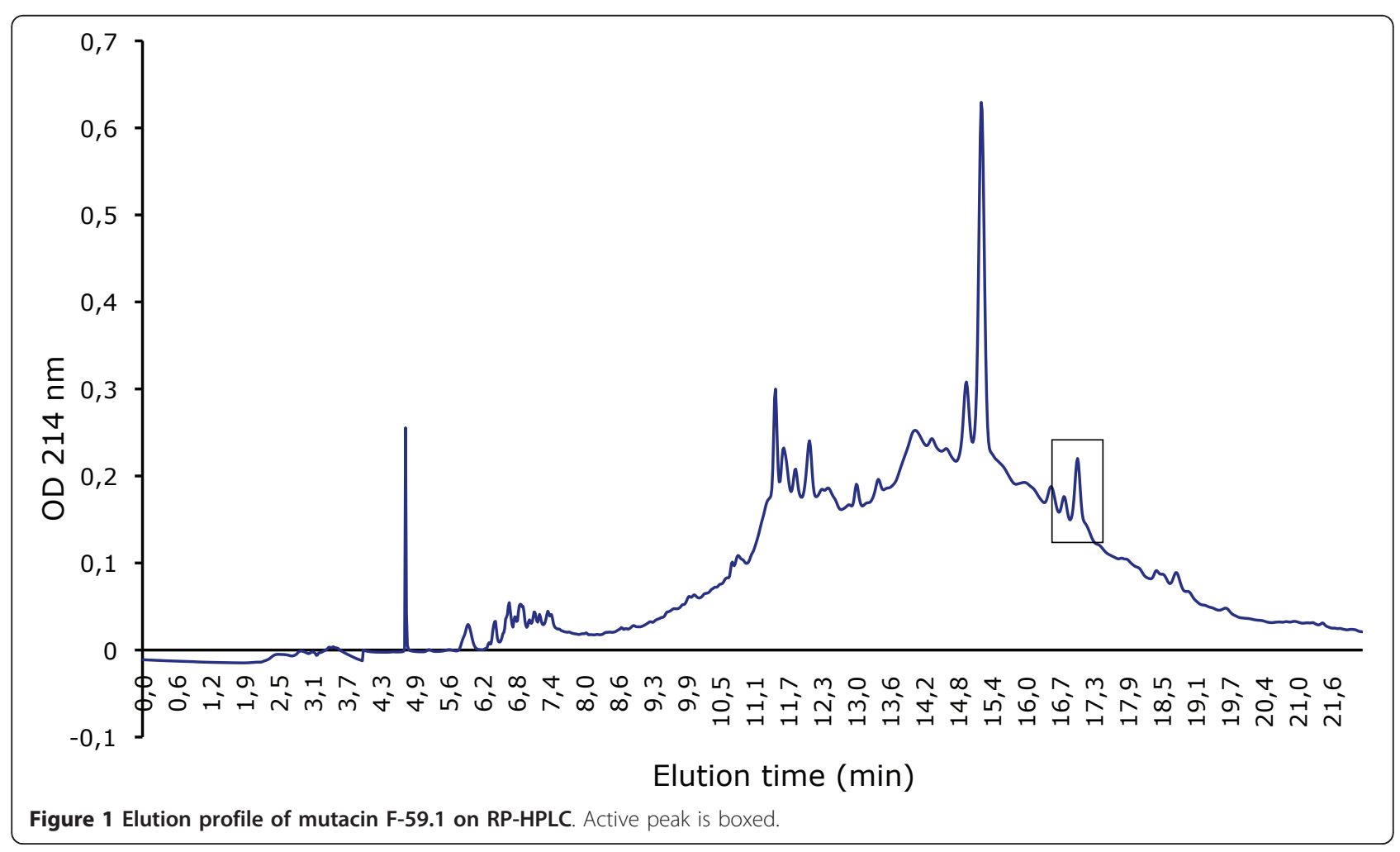




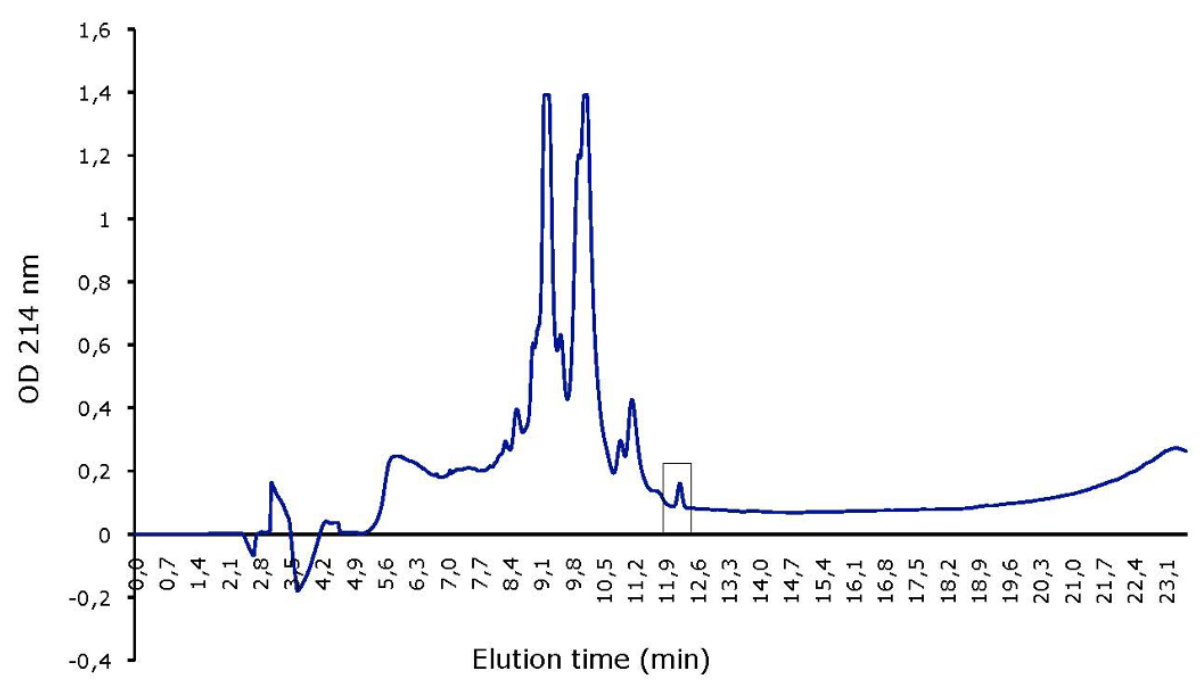

Figure 2 Elution profile of mutacin D-123.1 on RP-HPLC. Active peak is boxed.

the mutacin F-59.1 sequence with consensus amino acids found in our alignment (Figure 3) and those of others $[2,13]$, revealed that the following $\mathrm{N}$-terminal sequence KYYGNGVTCGKHSCSVDWSKATTNI matches the molecular mass determined by MALDI-TOF MS analysis (2720 Da +/- $2 \mathrm{Da}$, due to the formation of the current disulfide bridge found between $\mathrm{C} 9$ and $\mathrm{C} 14$ in pediocinlike bacteriocins [2], (Figure 4)). The isoelectric point of mutacin F-59.1 ( $\mathrm{pI}=8.71)$ and secondary structure prediction with this sequence correlate well with other class IIa bacteriocins (Figure 3) $[2,4]$.

The molecular mass for mutacin D-123.1 was computed to be $2364 \mathrm{Da}$ (Figure 5). However, sequencing of the mutacin D-123 proved to be problematic. Edman degradation of native mutacin D-123.1 was blocked after the first residue (F). The sequence of only the first 9 amino acids was clearly obtained after the derivatisation procedure, but with at least two peaks at each cycle.

The growth of M. luteus ATCC 272 was inhibited immediately following the addition of a purified preparation of mutacin F-59.1 at $160 \mathrm{AU} / \mathrm{mL}$ as the viable count decreased rapidly and dropped to zero compared to the control. Over an incubation period of $24 \mathrm{~h}$, the viable count of the test culture remained unchanged, suggesting that mutacin F-59.1 activity was bactericidal at the concentration tested (Figure 6).

The activity spectra observed for mutacins F-59.1 and D-123.1 show inhibition of a wide range of pathogenic bacteria including Bacillus spp., Enterococcus spp., Listeria spp.,

Staphylococcus spp. and Streptococcus spp. (Table 2).

\section{Discussion}

The inhibitory activity produced by the fermentation of S. mutans 59.1 in SWP did not come from release of pediocin already present in the whey proteins or permeate used to make the medium because no inhibitory activity in SWP was detected from non-fermented nor purified medium against M. luteus ATCC 272 and also because many other $S$. mutans strains were unable to produce an inhibitory activity by fermentation of the same medium [14,15].

Of all the current microbiological broth media commonly used for the growth of Streptococcus sp., none

Table 1 Purification of mutacins F-59.1 and D-123.1 by hydrophobic chromatography

\begin{tabular}{|c|c|c|c|c|c|c|c|}
\hline Step & $\begin{array}{l}\text { Volume } \\
(\mathrm{mL})\end{array}$ & $\begin{array}{l}\text { Activity } \\
\text { (AU/mL) }\end{array}$ & $\begin{array}{l}\text { Total Protein } \\
(\mathrm{mg})\end{array}$ & $\begin{array}{l}\text { Total activity } \\
\left(\mathrm{AU} .10^{3}\right)\end{array}$ & $\begin{array}{l}\text { Specific activity } \\
\text { (AU/mg) }\end{array}$ & $\begin{array}{l}\text { Yield } \\
(\%)\end{array}$ & $\begin{array}{l}\text { Purification } \\
\text { (fold) }\end{array}$ \\
\hline \multicolumn{8}{|l|}{ mutacin F-59.1 } \\
\hline Culture supernatant & 1000 & 400 & 10000 & 400 & 40 & 100 & 1 \\
\hline Sep-Pak $C_{18}$ & 95 & 3200 & 3000 & 304 & 101 & 76 & 2.5 \\
\hline $\mathrm{C}_{18} \mathrm{RP}-\mathrm{HPLC}$ & 2 & 16000 & 0.1 & 32 & $3.2 \times 10^{5}$ & 8 & $8 \times 10^{3}$ \\
\hline \multicolumn{8}{|l|}{ mutacin D-123.1 } \\
\hline$\overline{\text { Culture supernatant }}$ & 675 & 200 & 4320 & 135 & 31 & 100 & 1 \\
\hline Sep-Pak $C_{18}$ & 50 & 1600 & 8 & 80 & $1 \times 10^{4}$ & 59 & 320 \\
\hline $\mathrm{C}_{18} \mathrm{RP}-\mathrm{HPLC}$ & 1 & 800 & 0.005 & 0.8 & $1.6 \times 10^{5}$ & 0.2 & 5120 \\
\hline
\end{tabular}




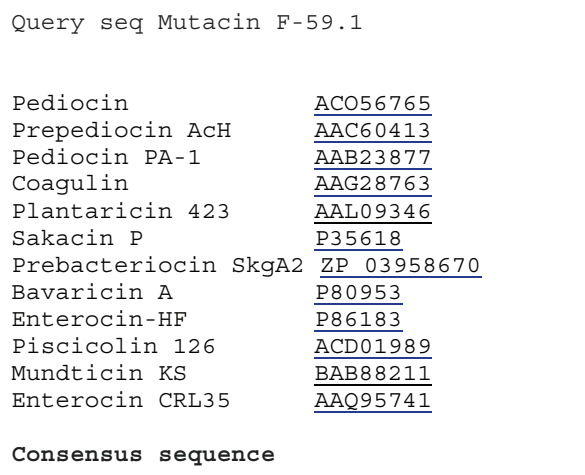

(5)

Figure 3 Multiple sequence alignment of mutacin F-59.1 with homologous class Ila bacteriocins. Consensus sequence appears in bold. Some of the leader sequences are shown with the double glycine motif. Underneath appears in italic the predicted secondary structure for mutacin F-59.1 and pediocin PA-1. Output classification is as follows: $\mathrm{H}$, alpha-helix; E, extended strand; T, turn; C, the rest [43]. Accession numbers refer to bacteriocins in the protein database from the NCBI (AAC60413, [44]; AAB23877, [45]; AAG28763, [46]; AAL09346, [47]; P35618, [48]; P80953, [49]; ACD01989, [50]; BAB88211, [51]; AAQ95741, [52]).

permitted the production of a detectable level of mutacin activity by $S$. mutans 123.1 . Activity of mutacin D123.1 was only detected after growth on solid medium. The production of some bacteriocins and mutacins is controlled by quorum sensing mechanisms which are better expressed when cells are grown at high density compared to lower cell density obtained in liquid culture [6]. For the isolation of mutacin D-123.1, agarose was preferred over agar as agar may contain compounds interfering with accurate detection of mutacin activity [16]. The nature of these compounds is still unknown, but divalent anions such as sulfates are suspected. As seen in previous work with other mutacins, purification yields were low (Table 1) and additional chromatographic steps will be necessary to improve yields and purity. The higher concentration of methanol used to recover mutacin D-123.1 suggests that the peptide is more hydrophobic than mutacin F-59.1. Collected samples of pure mutacin D-123.1 were very viscous because they probably retain part of the polymeric sugars from the agarose. However, with the methods used here, sufficient amounts of the substances were collected to carry

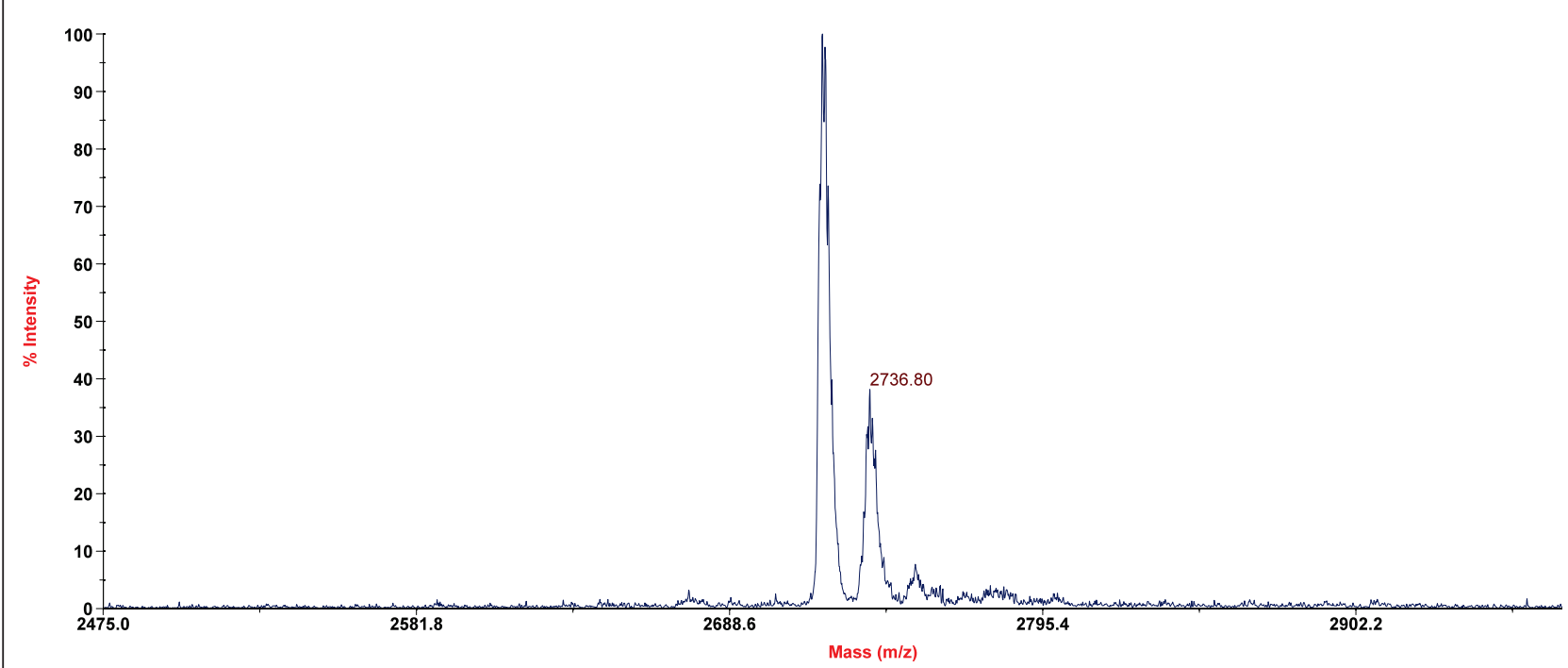

Figure 4 MALDI-TOF-MS spectra obtained for pure mutacin F-59.1. 


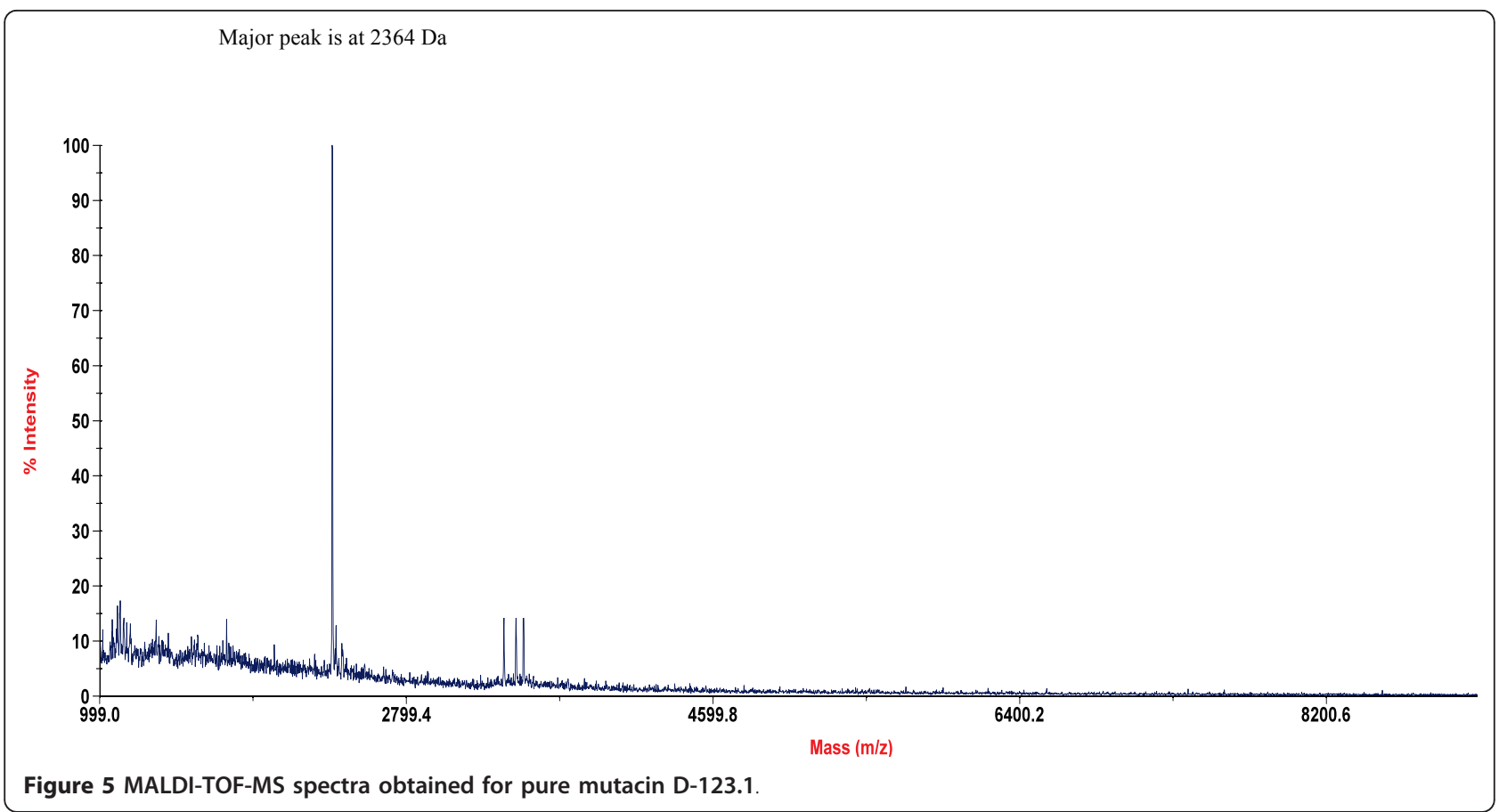

out a preliminary characterisation of the peptides but the evaluation of their antibacterial spectrum was somewhat restricted.

The sequence of mutacin F-59.1 (25 residues) was shorter than the generally recognised size for pediocinlike bacteriocins which is between 37 and 48 residues $[2,13]$. This may be due to peptidase activity of the strain. Fifty three peptidases or peptidase homologues are found in the genome of $S$. mutans UA159 using the MEROPS database $[17,18]$ http://merops.sanger.ac.uk. The pediocin-like bacteriocin sequence could thus be a substrate in its $25^{\text {th }}$ position for many of these peptidases. MALDI-TOF MS analysis revealed a major peak with an isotopic mass $[\mathrm{M}+\mathrm{H}]^{+}$of $2720 \mathrm{Da}$ for mutacin F-59.1 (Figure 4). This mass represents the lowest reported mass for an active naturally-produced pediocin-like bacteriocin after the study of Bhunia et al. [19]. The length of mutacin F-59.1 was sufficient to confer antimicrobial activity against several bacterial genera including Bacillus spp., Enterococcus spp., Lactococcus spp., Micrococcus spp., Listeria spp., and Streptococcus spp. (Table 2). Salvucci et al. [20] reported activity of short peptides derived from the $\mathrm{NH}_{2}$-terminus of enterocin CRL35 and other class IIa bacteriocins, suggesting that the C-terminus of pediocin-like bacteriocins is not essential for their inhibitory activity. Also, an active antimicrobial region in the $\mathrm{NH}_{2}$-terminus of this class of bacteriocin was identified by a bioinformatic approach [21]. The C-terminus section is known to confer specificity in the activity spectra of class IIa bacteriocins and to interact with their cognate immunity proteins [22].
Pediocin-like bacteriocins are unstructured in an aqueous solution and become structured when in contact with membrane-mimicking entities [2]. The electrostatic distribution along the molecule is highly polarized with most of the cationic residues concentrated in the $\mathrm{N}$ terminal region. In the model class IIa bacteriocin sakacin $\mathrm{P}$, the N-terminal residues in positions 7-9 (V-T-C) and 15-17 (S-V-D) are predicted to form an anti-parallel $\beta$-sheet-like structure stabilised by a conserved disulfide bridge, followed by a hairpin-like structure that consists of an amphiphilic $\alpha$-helix in position 18-25 (W-G-K-AI-G-I-I). A second $\alpha$-helix normally found in pediocinlike bacteriocins at position 29-32 (S-A-A-N) with the $\mathrm{C}$-terminal tail (residue 33 to the end) that folds back onto the central $\alpha$-helix is absent in mutacin F-59.1. A flexible hinge is found in position 17 (D) between the $\mathrm{N}$-terminal $\beta$ strands and the hairpin-like C-terminal region [23]. Studies on the conformational changes of pediocin in an aqueous medium were conducted by Gaussier et al. [24]. The authors concluded that the flexibility of the protein ensures its activity and that the aggregation of the C-terminus caused a loss of activity. Lack of the C-terminus in mutacin F-59.1 should prevent the formation of such aggregates and does not disrupt the activity of the molecule. The predicted secondary structure of mutacin F-59.1 appears to differ slightly from that of pediocin PA-1. An $\alpha$-helix is formed between residues 2 to 11 and a turn is found at position 14-15 as compared to position 18-19 of pediocin PA-1. The positions of the disulfide bridges were correctly predicted between positions C9-C14 for 


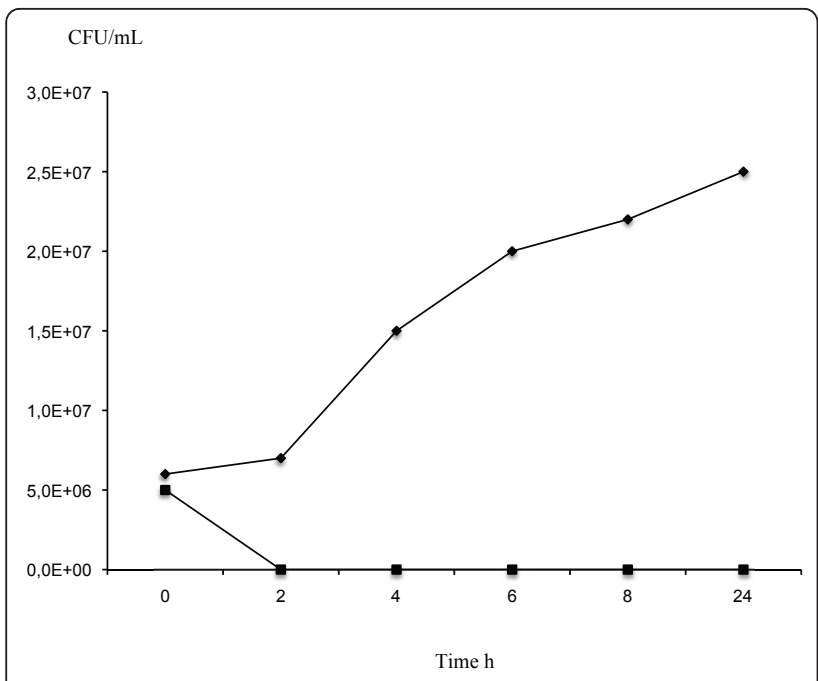

Figure 6 Inhibitory action of purified mutacin F-59.1 against Micrococcus luteus ATCC 272. Growth of cells was followed by measuring the viable count (CFU/mL) following the addition of purified mutacin F-59.1 (1600 AU/mL) (square line) or not for control (diamond line).

mutacin F-59.1 and between positions C9-C14 and C24C44 for pediocin PA-1 (data not shown).

As for mutacin I, Edman degradation of native mutacin D-123.1 was blocked after the first residue $(\mathrm{F})$, suggesting that the second residue (probably an $\mathrm{S}$ residue) was dehydrated as dehydrated amino acids in lantibiotics were shown to block Edman degradation $[25,26]$. Following close inspection using the relative intensity of each peak as a reference and the fact that ethanethiol treatment broke mutacin I into two fragments according to Qi et al. [25], therefore creating two N-termini peptides in the mixture to be sequenced, we reasoned and found the following partial amino acid sequence for mutacin D-123.1: F-SEC-SEC/DSER-L-SEC-L-SEC-SEC/DSER-L-(...)-PSEC/DSER-F-N-SEC/DSER-Y-SEC-SEC. According to Meyer et al. [26], SEC results from the conversion of a dhA while a SEC signal accompanied by a DSER signal indicates residues involved in Lan (A) formation, making the thioether bridge. Based on these observations and by analogy to mutacin I, a more accurate, partial and truncated sequence with structural thioether bridges positions can be proposed for mature mutacin D-123.1. The sequence of the two separate fragments obtained for the mutacin D-123.1 is as follows:

Nter-F-S-S-L-S-L-C-S-L-(...)-P-S-F-N-S-Y-C-C

Nter-F-dhA-A-L-dhA-L-A-A-L-(...)-P-A-F-N-A-Y-AA.

(A) residues are involved in Lan formation. At this stage, an accurate thioether bridge pattern of mutacin
Table 2 Inhibitory spectra of purified mutacins F-59

\begin{tabular}{|c|c|c|}
\hline \multirow[t]{2}{*}{ Indicator bacteria } & \multicolumn{2}{|c|}{ Activity of mutacin $(\mathrm{AU} / \mathrm{mL})$} \\
\hline & D-123.1 & F-59.1 \\
\hline Bacillus cereus ATCC 2 & n.t. $^{\text {a }}$ & 400 \\
\hline Bacillus subtilis ATCC 6051 & n.t. & 400 \\
\hline Enterococcus faecium ATCC 19434 & 0 & 1600 \\
\hline Enterococcus faecalis ATCC 27235 & 400 & 200 \\
\hline Enterococcus hirae ATCC 8043 & 200 & 200 \\
\hline Lactobacillus salivarius SMQ 876 & n.t. & 0 \\
\hline Lactococcus lactis ATCC 11454 & 400 & 400 \\
\hline Listeria monocytogenes ATCC 15313 & 400 & $200^{b}$ \\
\hline L. monocytogenes ATCC 700301 ScottA & 200 & $200^{b}$ \\
\hline L. monocytogenes ATCC 700302 ScottA & 200 & $200^{b}$ \\
\hline L. monocytogenes FRDC 1039 & 400 & $200^{\mathrm{b}}$ \\
\hline L. monocytogenes FRDC 88571 & 400 & $200^{b}$ \\
\hline Listeria murrayi ATCC 25420 & 200 & $200^{b}$ \\
\hline L. murrayi HPB 30 & 400 & $200^{b}$ \\
\hline Listeria ivanovii HPB 28 & 400 & 200 \\
\hline Listeria grayi ATCC 19120 & 800 & 200 \\
\hline Micrococcus luteus ATCC 272 & 11600 & 3200 \\
\hline Pediococcus acidilactici UL5 & 400 & 800 \\
\hline Staphylococcus aureus ATCC 6538 & n.t. & 0 \\
\hline S. aureus ATCC 25923 & 0 & 0 \\
\hline S. aureus ATCC 43300 & 200 & 0 \\
\hline S. aureus R621 & 200 & 0 \\
\hline Staphylococcus carnosus & 1600 & 800 \\
\hline Streptococcus mutans 59.1 & n.t. & $200^{b}$ \\
\hline S. mutans 123.1 & $200^{d}$ & n.t. \\
\hline Streptococcus sobrinus ATCC 27352 & 200 & 800 \\
\hline Streptococcus salivarius ATCC 25923 & 800 & 800 \\
\hline Streptococcus pyogenes ATCC 10389 & 200 & 0 \\
\hline Streptococcus suis serotype 2 & 400 & 0 \\
\hline
\end{tabular}

ATCC (Manassas, VA, USA); HPB (Health Canada, Ottawa, ON, Canada); FRDC (Agriculture and Agrifood Canada, Sainte-Hyacinthe, QC, Canada).

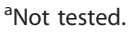

${ }^{\mathrm{b}}$ Hazy inhibition zone was observed.

D-123.1 cannot be proposed unambiguously. The mass of mutacin D-123.1 matched exactly that calculated for the lantibiotic mutacin I produced by S. mutans $\mathrm{CH} 43$ and UA140 (2364 Da) [25,27]. This observation strengthens the apparent identity between mutacin D123.1 and mutacin I.

The activity spectra of purified mutacins F-59.1 and D-123.1 are in accordance with the antibacterial activity spectra of the respective producing strains inhibiting Bacillus cereus, Enterococcus spp., Listeria monocytogenes, Staphylococcus spp. and Streptococcus spp. using the deferred antagonism assay and thus observed for other purified pediocin-like bacteriocins and mutacins $[2,7,8,13,19,22,27]$. However, some of the strains tested, particularly Listeria spp., were less sensitive to the activity of purified mutacin F-59.1 than to the producer strain itself [8]. This may be due to the production by 
S. mutans 59.1 of more than one mutacin in solid medium having activity against Listeria spp.. Also, resistance to pediocin-like bacteriocins in Listeria species has already been reported and can be physiologically or genetically acquired [28,29]. Low levels of resistance are caused by alterations in membrane lipid composition while high resistance levels involved the loss of a mannose permease component [30,31].

Nisin resistance is also reported and is related to membrane composition [32] or alterations in the cell wall [33]. Our results show that nisin-resistant Listeria strains were still sensitive to the lantibiotic mutacin D-123.1. Lipid II-targeted lantibiotics that are too short to form a pore across the bilayer membrane can still maintain their antibacterial activity to be able to kill the nisin-resistant strains In a similar manner, mutacin D-123.1 could act by trapping lipid II from the septum, blocking peptidoglycan synthesis and leading to cell death [34]. Moreover, activity of mutacin D-123.1 against antibiotic-resistant Enterococcus spp. and Staphylococcus spp. stresses its potential as a new antibiotic. Weak activity of mutacins F-59.1 and D-123.1 were observed against their respective producing strains (S. mutans 59.1 and 123.1) as compared to the highly sensitive strain M. luteus ATCC 272, which suggests that the respective strains are able to produce specific self-immunity factors. Bacteriocin biosynthesis genes are generally co-transcribed with a gene encoding a cognate immunity protein ensuring protection of the producing cell against the lethal activity of the bacteriocin they produce [4].

Pediocin-like bacteriocins were identified in a wide variety of Gram positive bacteria such as Bacillus spp., Carnobacterium spp., Enterococcus spp., Lactobacillus spp., Leuconostoc spp., Listeria spp. [2,13]. While high heterogeneity has been observed in the genetic determinants coding for production of mutacins [12,35], this is the first report of a pediocin-like mutacin produced by $S$. mutans, which further extends the distribution of pediocin-encoding genes as well as the antibacterial spectra of $S$. mutans against pathogens sensitive to class IIa bacteriocins. From the two genomes of S. mutans strains available in public databases (UA159 in GenBank under accession number AE014133 and NN2025 in the DNA databank of Japan under accession number AP010155) [17,36], no lantibiotic nor pediocin-like bacteriocin sequences were found, although many bacteriocin-related genes are detected [6]. Only some entries with bacteriocin_II superfamily proteins (pfam01721) in the NCBI database matched two pediocin family proteins from Streptococcus bovis ATCC 700338 and Streptococcus mitis ATCC 6249 (EFM26697.1 and EFM30880.1). To our knowledge, only a Streptococcus uberis strain was shown to produce a pediocin-like bacteriocin named ubericin A [37]. Production of bacteriocins is widely distributed among strains of $S$. mutans. Lantibiotic-type mutacin production is sporadically detected from strains isolated from different origins; this strongly suggests the existence of a common genomic ancestor element for lantibiotic biosynthesis [6]. Comparative genomic analysis reported that dispensable genes exist and have been scattered through horizontal genetic transfer in various $S$. mutans strains. These optional mobile genes may be selected when they provide competitiveness to the strains as in the case of bacteriocin production to compete with the numerous other bacterial species resident in the oral cavity [38].

\section{Conclusion}

Two bacteriocins from $S$. mutans have been isolated and characterised in terms of molecular mass, sequence and activity spectra. Mutacin F-59.1 is related to pediocinlike bacteriocins and is the first one shown to be produced by S. mutans. Mutacin D-123.1 appears identical to mutacin I in molecular mass and in the N-terminus sequence. Antibacterial activity spectra of these mutacins indicate promising potential application by inhibiting numerous bacterial pathogens. More research remains to be done to increase the low yields of mutacin production and purification.

\section{Methods}

\section{Bacterial strains and media}

Streptococcus mutans 59.1 and 123.1 produce mutacins F-59.1 and D-123.1 respectively [8]. Micrococcus luteus ATCC 272 (ATCC, Manassas, VA, USA) was used as the indicator strain for the mutacin activity assays. All bacteria were routinely grown aerobically at $37^{\circ} \mathrm{C}$ in TSBYE made of TSB (Difco laboratories, Detroit, MI, USA) supplemented with $0.3 \%$ yeast extract (Becton Dickinson \& Co., Cockeysville, MD, USA) or on TSAYE plates made of TSA (Difco) enriched with $0.3 \%$ yeast extract. Lactobacillus salivarius strain (provided by Sylvain Moineau, Université Laval, Québec, QC, Canada) was cultivated aerobically at $30^{\circ} \mathrm{C}$ in MRS medium (Oxoid, Nepean, ON, Canada). Other bacterial strains used for the inhibitory spectra determination are described in Mota-Meira et al. [7] and Morency et al. [8]. Staphylococcus carnosus was obtained from the strain collection of the Department of Microbiology, Biochemistry and Bioinformatics (Université Laval).

\section{Production of mutacins}

An overnight culture of the producing strain Streptococcus mutans 59.1 in TSBYE was used to inoculate (1\% v/ v) $2 \mathrm{~L}$ of supplemented whey permeate (SWP) consisting of cheese whey permeate $6 \%(\mathrm{w} / \mathrm{v})$ (kind gift from Agropur Coop., Granby, QC, Canada) supplemented with $1 \% \mathrm{CaCO}_{3}$ (Anachemia, Montréal, QC, Canada) 
and 2\% yeast extract (Institut Rosell, Montréal, QC, Canada). The culture was incubated $48 \mathrm{~h}$ at $37^{\circ} \mathrm{C}$ under aerobic conditions, centrifuged at $10000 \times g$ for $10 \mathrm{~min}$ and the supernatant was heated at $70^{\circ} \mathrm{C}$ for $10 \mathrm{~min}$ to destroy the remaining cells and enzyme activity [14].

Mutacin D-123.1 was produced in TSBYE (Difco) containing $0.5 \%$ agarose (Difco). Batches of this medium $(4 \mathrm{~L})$ were stab inoculated with a culture of $S$. mutans 123.1 grown in TSBYE and incubated for $72 \mathrm{~h}$ at $37^{\circ} \mathrm{C}$. After growth, the culture was scraped, aliquoted into centrifuge bottles and frozen overnight at $-20^{\circ} \mathrm{C}$. The bottles were then centrifuged at $4000 \times g$ for $60 \mathrm{~min}$ and $8000 \times g$ for $30 \mathrm{~min}$ at room temperature. The resulting supernatant was filtered through glass fibers and Whatman no. 1 filter paper to remove agarose fines then stored at $4^{\circ} \mathrm{C}$.

\section{Purification of mutacins}

Purification of the two mutacins was achieved by two hydrophobic chromatography steps as previously described $[15,39]$ by replacing TFA with $\mathrm{HCl}(10 \mathrm{mM})$ [40]. Briefly, the active preparation was loaded on a SepPak $^{\circledR}$ Vac 35 cc $(10 \mathrm{~g}) \mathrm{t}-\mathrm{C}_{18}$ Cartridge (Waters Corporation, Milford, MA, USA). Cartridges were first equilibrated with $500 \mathrm{~mL}$ of methanol followed by $500 \mathrm{~mL}$ of deionized distilled water. Antibacterial compounds were eluted with successive steps of $500 \mathrm{~mL}$ of water:methanol mixtures increasing the gradient of methanol by $10 \%$ from 0 to $100 \%$ in $10 \mathrm{mM} \mathrm{HCl}$. This was carried out at a flow rate of $1 \mathrm{~mL} / \mathrm{min}$ and UV detection at $214 \mathrm{~nm}$. The final purification step was carried out by reverse phase chromatography (RP)-HPLC analysis (Beckman Gold Model, Coulter Canada Inc., Mississauga, ON, Canada) using an analytical $\mathrm{C}_{18}$ column (Luna $5 \mu \mathrm{C} 18(2), 250 \times 4.6 \mathrm{~mm}, 4 \times 3.0 \mathrm{~mm}$, Phenomenex, Torrance, CA, USA). Elution was carried out with solvent $\mathrm{A}(5 \%$ acetonitrile, $10 \mathrm{mM} \mathrm{HCl})$ and solvent $\mathrm{B}$ $(60 \%$ acetonitrile, $10 \mathrm{mM} \mathrm{HCl})$ and recorded at $214 \mathrm{~nm}$. The following program of elution was developed: 0 to 3 min, constant $100 \% \mathrm{~A} ; 3$ to $15 \mathrm{~min}$, a linear gradient from $100 \%$ A to $100 \%$ B; 15 to 20 min, constant $100 \%$ B; 20 to $23 \mathrm{~min}$, a linear gradient from $100 \%$ B to $100 \%$ A. A flow rate of $1 \mathrm{~mL} / \mathrm{min}$ was used. The column was maintained at $39^{\circ} \mathrm{C}$ with a column heater. Active fractions were manually collected, subsequently dried in a Speed-Vac ${ }^{\circledR}$ concentrator (Model SC110A, Savant Instrument Inc. Farmingdale, NY, USA) and then kept at $-20^{\circ} \mathrm{C}$ until processing. Protein concentration in active fractions was determined using the BioRad DC protein assay (BioRad, Mississauga, ON, Canada).

\section{Activity assay of mutacins}

Mutacin activity was determined by the spot test using Micrococcus luteus ATCC 272 as sensitive strain where two-fold dilutions were prepared in acidified $(\mathrm{pH} 2)$ peptone water (0.5\%) [14]. Antibacterial activity spectra of purified mutacins was tested against a panel of bacterial strains using the critical dilution method combined with the spot test method as described previously [14]. Briefly, overnight cultures of test strains in TSBYE were diluted in fresh broth before inoculating $5 \mathrm{~mL}$ of soft agar $(0.75 \%)$ in order to obtain confluent lawns of growth on TSAYE plates. Five $\mu \mathrm{L}$ of purified mutacins, diluted in acidified $(10 \mathrm{mM} \mathrm{HCl})$ distilled water to promote solubility of the peptides, were deposited on the lawn and allowed to dry before appropriate incubation. Mutacin activity was expressed in $\mathrm{AU} / \mathrm{mL}$ and corresponds to the reciprocal of the highest dilution showing a noticeable inhibition zone on the lawn [14].

\section{Amino acid sequencing procedure}

Alkaline ethanethiol derivatisation as described by Meyer et al. [26] was performed prior to sequencing of mutacins. Briefly, the purified sample was vacuum dried and was dissolved in $30 \mu \mathrm{L}$ of a derivatisation mixture composed of 1.4 $\mathrm{M}$ ethanethiol and $0.5 \mathrm{M} \mathrm{NaOH}$ in $46 \%$ aqueous ethanol. The sample was then incubated for $60 \mathrm{~min}$ at $50^{\circ} \mathrm{C}$ in limited oxygen atmosphere. The reaction was stopped by the addition of $2 \mu \mathrm{L}$ of glacial acetic acid (Sigma-Aldrich, St Louis, MO, USA) just before sequencing. Pure mutacin B-Ny266 was used as control for the Edman degradation with the alkaline ethanethiol derivatisation procedure [39]. Automated Edman degradation was performed on a protein sequencer (ABI Procise cLC, Applied Biosystems, Foster City, CA, USA) at the Biotechnology Research Institute (Montréal, QC, Canada). Amino acids were identified by capillary HPLC on a $\mathrm{C}_{18} 0.8 \times 150 \mathrm{~mm}$ column.

\section{Characterisation of mutacins by bioinformatic analyses}

Homology searches were carried out with the National Center of Biotechnology Information (NCBI) using the basic local alignment search tool for protein (BLAST-P) with default parameters [41]. The constraint-based multiple alignment tool (COBALT) from NCBI was used with the default parameters to perform alignment. The primary and secondary structures of the mutacin F-59.1 were analyzed by the ExPASy Proteomics Server http://ca.expasy. org/tools/\#proteome[42] and the SCRATCH protein predictor http://scratch.proteomics.ics.uci.edu/[43].

\section{Molecular mass analysis}

The molecular masses of mutacins (D-123.1 and F-59.1) were determined from pure HPLC fractions by MALDITOF MS analyses at the Mass Spectrometry Laboratory of Molecular Medicine Research Centre (University of Toronto, Toronto, ON, Canada). A saturated $\beta$-cyano-4hydroxycinnamic acid in $70 \%$ acetonitrile and $0.1 \%$ TFA 
was used as the matrix solution. One $\mu \mathrm{L}$ of peptide sample was spotted on the sample target, and then $1 \mu \mathrm{L}$ of saturated matrix solution was added on the top. After the crystal was formed, the sample target was inserted into the mass spectrometer. MALDI MS was acquired in linear mode at positive on Applied Biosystems Voyager-DE STR MALDI-TOF mass spectrometer (Applied Biosystems, Foster City, CA, USA) equipped with a 337 $\mathrm{nm}$ laser. Acceleration voltage was set at $20 \mathrm{kV}$, grid voltage at $94 \%$, guide wire at $0.05 \%$, and delay time at $175 \mathrm{nsec}$. The mass spectra were externally calibrated by the molecular weights of a mixture of standard peptides. The mass accuracy is typically $0.05 \%$.

\section{Protein sequence accession number}

The protein sequence data of the mutacin F-59.1 appears in the UniProt Knowledgebase under the accession number P86386.

\section{Inhibitory effect of mutacin F-59.1}

One milliliter of active preparation (1600 AU/mL) adjusted to $\mathrm{pH} 7.0$ was filter sterilised then added to 10 $\mathrm{mL}$ of an early-log-phase culture of Micrococcus luteus ATCC 272 grown in TSBYE. Bacterial culture in TSBYE was used as a negative control. The viable count in $\mathrm{CFU} / \mathrm{mL}$ was determined at intervals for up to $24 \mathrm{~h}$ for samples and control during incubation at $37^{\circ} \mathrm{C}$ by plating $100 \mu \mathrm{L}$ of an appropriate dilution in peptone water $(0.1 \%)$ on TSAYE incubated at $37^{\circ} \mathrm{C}$ at least $24 \mathrm{~h}$.

\begin{abstract}
Abbreviations
ATCC: American Type Culture Collection; AU: arbitrary units; CFU: colonyforming units; dhA: 2,3-didehydroalanine; DSER: PTH-dithiothreitiol adduct of dhA; FRDC: Food Research and Development Center; Lan: lanthionine; $\mathrm{HCl}$ : hydrochloric acid; HPB: Health Protection Branch; MALDI-TOF MS: matrix assisted laser desorption ionisation-time of flight mass spectrometry; MRS: de Man Rogosa Sharpe; nsec: nanosecond; PTH: phenylthiohydantoin; RP-HPLC: reverse-phase high-pressure liquid chromatography; SWP: supplemented whey permeate; SEC: S-ethylcysteine; TFA: trifluoroacetic acid; TSA(B)YE: trypticase soy agar (broth) yeast extract; Amino acid one letter code is used.
\end{abstract}

\section{Acknowledgements}

This work was supported by the Natural Sciences and Engineering Research Council of Canada (NSERC). We are grateful to Jean Barbeau of University of Montréal allowing sequencing of mutacin D-123.1. We thank Alain Gaudreau of the STELA Dairy Research Center of Université Laval for technical assistance in the purification process and France Dumas from the Biotechnology Research Institute of Montréal for the sequencing procedure. We also thank Johnny Basso of University of Ottawa and Franck Stefani from Canadian Forest Service (Québec) for their critical review of the manuscript. Guillaume Nicolas is supported by a University-Industry Ph.D. Scholarship from NSERC and Microbio LCA Inc. Marc C. Lavoie is supported by a grant from the Caribbean Health Research Council to study mutacins.

\section{Author details}

'Département de Biochimie Microbiologie et Bioinformatique, Faculté des Sciences et Génie, Université Laval, Québec (Québec), G1K 7P4, Canada. ${ }^{2}$ Centre de Recherche en Sciences et Technologie du Lait (STELA), Institut des Nutraceutiques et des Aliments Fonctionnels (INAF), Faculté des Sciences de l'Agriculture et de l'Alimentation, Université Laval, Québec
(Québec), G1V 0A6, Canada. ${ }^{3}$ Département de Stomatologie, Faculté de Médecine Dentaire, Université de Montréal, Montréal (Québec), H3C 3J7, Canada. ${ }^{4}$ Department of Biological and Chemical Sciences, Faculty of Pure and Applied Sciences, The University of the West Indies, Cave Hill Campus, P. O. Box 64 Bridgetown, BB11000, Barbados.

\section{Authors' contributions}

GN participated in project conception, coordinated and carried out most of the experiments, analysed and interpreted data and wrote the manuscript. $\mathrm{GL}$ designed and supervised the analyses and corrected the manuscript. $\mathrm{MCL}$ conceived the study and participated in its design as well as in correction of the manuscript. All authors read and approved the final manuscript.

Received: 29 September 2010 Accepted: 10 April 2011

Published: 10 April 2011

\section{References}

1. Fischbach MA, Walsh CT: Antibiotics for emerging pathogens. Science 2009, 325:1089-1093.

2. Drider D, Fimland $G$, Héchard $Y$, McMullen LM, Prévost $H$ : The continuing story of class lla bacteriocins. Microbiol Mol Biol Rev 2006, 70:5 64-82.

3. Smith L, Hillman JD: Therapeutic potential of type A (I) lantibiotics, a group of cationic peptide antibiotics. Curr Opin Microbiol 2008, 11:401-408.

4. Jack RW, Tagg RJ, Ray B: Bacteriocins of Gram-positive bacteria. Microbiol Rev 1995, 59:171-200.

5. Asaduzzaman SM, Sonomoto K: Lantibiotics: diverse activities and unique modes of action. J Biosci Bioeng 2009, 107:475-487.

6. Nicolas GG, Lavoie MC, Lapointe G: Molecular genetics, genomics and biochemistry of mutacins. Genes, Genomes and Genomics 2007, 1:193-208.

7. Mota-Meira M, LaPointe G, Lacroix C, Lavoie MC: MICs of mutacin B-Ny266, nisin $\mathrm{A}$, vancomycin, and oxacillin against bacterial pathogens. Antimicrob Agents Chemother 2000, 44:24-29.

8. Morency H, Mota-Meira M, LaPointe G, Lacroix C, Lavoie MC: Comparison of the activity spectra against pathogens of bacterial strains producing a mutacin or a lantibiotic. Can J Microbiol 2001, 47:322-331.

9. Mota-Meira M, Morency H, Lavoie MC: In vivo activity of mutacin B-Ny266. J Antimicrob Chemother 2005, 56:869-871.

10. Nicolas GG, Mota-Meira M, Lapointe G, Lavoie MC: Mutacins and their potential use in food preservation. Food 2007, 1:161-171.

11. Morency $H$, Trahan L, Lavoie MC: Preliminary grouping of mutacins. Can J Microbiol 1995, 41:826-831.

12. Bekal-Si Ali S, Hurtubise Y, Lavoie MC, LaPointe G: Diversity of Streptococcus mutans bacteriocins as confirmed by DNA analysis using specific molecular probes. Gene 2002, 283:125-131.

13. Fimland G, Johnsen L, Dalhus B, Nissen-Meyer J: Pediocin-like antimicrobial peptides (class lla bacteriocins) and their immunity proteins: biosynthesis, structure, and mode of action. J Pept Sci 2005, 11:688-696.

14. Nicolas G, Auger I, Beaudoin M, Halle F, Morency H, LaPointe G, Lavoie MC: Improved methods for mutacin detection and production. J Microbiol Methods 2004, 59:351-361.

15. Nicolas G, Morency H, LaPointe G, Lavoie MC: Mutacin H-29B is identical to mutacin II (J-T8). BMC Microbiol 2006, 6:36.

16. Hillman JD, Novak J, Sagura E, Gutierrez JA, Brooks TA, Crowley PJ, Hess M, Azizi A, Leung KP, Cvitkovitch D, Bleiweis AS: Genetic and biochemical analysis of mutacin 1140, a lantibiotic from Streptococcus mutans. Infect Immun 1998, 66:2743-2749.

17. Ajdic D, McShan WM, McLaughlin RE, Savic G, Chang J, Carson MB, Primeaux C, Tian R, Kenton S, Jia H, Lin S, Qian Y, Li S, Zhu H, Najar F, Lai H, White J, Roe BA, Ferretti JJ: Genome sequence of Streptococcus mutans UA159, a cariogenic dental pathogen. Proc Natl Acad Sci USA 2002, 99:14434-14439

18. Rawlings ND, Morton FR, Kok CY, Kong J, Barrett AJ: MEROPS: the peptidase database. Nucleic Acids Res 2008, 36:D320-D325.

19. Bhunia AK, Johnson MC, Ray B: Purification, characterization and antimicrobial spectrum of a bacteriocin produced by Pediococcus acidilactici. J Appl Bacteriol 1988, 65:261-268.

20. Salvucci E, Saavedra L, Sesma F: Short peptides derived from the $\mathbf{N H}_{2}$ terminus of subclass lla bacteriocin enterocin CRL35 show antibacterial activity. J Antimicrob Chemother 2007, 59:1102-1108. 
21. Torrent M, Nogués VM, Boix E: A theoretical approach to spot active regions in antimicrobial proteins. BMC Bioinformatics 2009, 10:373.

22. Johnsen L, Fimland G, Nissen-Meyer J: The C-terminal domain of pediocinlike antimicrobial peptides (class lla bacteriocins) is involved in specific recognition of the C-terminal part of cognate immunity proteins and in determining the antimicrobial spectrum. J Biol Chem 2005, 280:9243-9250.

23. Uteng M, Hauge HH, Markwick PR, Fimland G, Mantzilas D, Nissen-Meyer J, Muhle-Goll C: Three-dimensional structure in lipid micelles of the pediocin-like antimicrobial peptide sakacin $P$ and a sakacin $P$ variant that is structurally stabilized by an inserted C-terminal disulfide bridge. Biochemistry 2003, 42:11417-11426.

24. Gaussier H, Lavoie M, Subirade M: Conformational changes of pediocin in an aqueous medium monitored by Fourier transform infrared spectroscopy: a biological implication. Int J Biol Macromol 2003, 32:1-9.

25. Qi F, Chen P, Caufield PW: Purification and biochemical characterization of mutacin I from group I strain of Streptococcus mutans, CH43, and genetic analysis of mutacin I biosynthesis genes. Appl Environ Microbiol 2000, 66:3221-3229.

26. Meyer HE, Heber M, Eisermann B, Korte H, Metzger JW, Jung G: Sequence analysis of lantibiotics: chemical derivatization procedures allow a fast access to complete Edman degradation. Anal Biochem 1994, 223:185-190.

27. Qi F, Chen P, Caufield PW: The group I strain of Streptococcus mutans, UA140, produces both the lantibiotic mutacin I and a nonlantibiotic bacteriocin, mutacin IV. Appl Environ Microbiol 2001, 67:15-21.

28. Ennahar S, Deschamps N, Richard J: Natural variation in susceptibility of Listeria strains to class Ila bacteriocins. Curr Microbiol 2000, 41:1-4.

29. Tessema GT, Moretro T, Kholer A, Axelsson L, Naterstad K: Complex phenotypic and genotypic response of Listeria monocytogenes strains exposed to the class Ila bacteriocin sakacin P. Appl Environ Microbiol 2009, 75:6973-6980

30. Vadyvaloo V, Arous S, Gravesen A, Héchard Y, Chauhan-Haubrock R, Hastings JW, Rautenbach M: Cell-surface alterations in class Ila bacteriocin-resistant Listeria monocytogenes strains. Microbiology 2004 150:3025-3033.

31. Arous S, Dalet $K$, Héchard Y: Involvement of the mpo operon in resistance to class lla bacteriocins in Listeria monocytogenes. FEMS Microbiol Lett 2004, 238:37-41.

32. Mazzotta AS, Montville TJ: Nisin induces changes in membrane fatty acid composition of Listeria monocytogenes nisin-resistant strains at $10^{\circ} \mathrm{C}$ and $30^{\circ} \mathrm{C}$. Appl Environ Microbiol 1997, 82:32-38.

33. Garde $S$, Avila M, Medina M, Nunez M: Fast induction of nisin resistance in Streptococcus thermophilus INIA 463 during growth in milk. Int J Food Microbiol 2004, 96:165-172.

34. Hasper HE, Kramer NE, Smith JL, Hillman JD, Zachariah C, Kuipers OP, de Kruijff B, Breukink E: An alternative bactericidal mechanism of action for lantibiotic peptides that target lipid II. Science 2006, 313:1636-1637.

35. Kamiya RU, Höpfling JF, Gonçalves RB: Frequency and expression of mutacin biosynthesis genes in isolates of Streptococcus mutans with different mutacin-producing phenotypes. J Med Microbiol 2008, 57:626-635.

36. Maruyama F, Kobata M, Kurokawa K, Nishida K, Sakurai A, Nakano K, Nomura R, Kawabata S, Ooshima T, Nakai K, Hattori M, Hamada S, Nakagawa I: Comparative genomic analysis of Streptococcus mutans provide insights into chromosomal shuffling and species-specific content. BMC Genomics 2009, 10:358.

37. Heng NC, Burtenshaw GA, Jack RW, Tagg JR: Ubericin A, a class Ila bacteriocin produced by Streptococcus uberis. Appl Environ Microbiol 2007, 73:7763-7766

38. Waterhouse JC, Russell RR: Dispensable genes and foreign DNA in Streptococcus mutans. Microbiology 2006, 152:1777-1788.

39. Mota-Meira M, Lacroix C, LaPointe G, Lavoie MC: Purification and structure of the mutacin B-Ny266: a new lantibiotic produced by Streptococcus mutans. FEBS Letters 1997, 410:275-279.

40. Morency H, Lavoie MC, Subirade M: Replacement of trifluoroacetic acid with $\mathrm{HCl}$ in the hydrophobic purification steps of pediocin PA-1: a structural effect. Appl Environ Microbiol 2002, 68:4803-4808.

41. Altschul SF, Madden TL, Schäffer AA, Zhang J, Zhang Z, Miller W, Lipman DJ: Gapped BLAST and PSI-BLAST: a new generation of protein database search programs. Nucleic Acids Res 1997, 25:3389-3402.

42. Gasteiger E, Hoogland C, Gattiker A, Duvaud S, Wilkins MR, Appel RD, Bairoch $A$ : Protein identification and analysis tools on the ExPASy server.
In The Proteomics Protocols Handbook. Edited by: John M Walker. Humana Press; 2005:571-607.

43. Cheng J, Randall A, Sweredoski M, Baldi P: SCRATCH: a protein structure and structural feature prediction server. Nucleic Acids Res 2005, , 33 web server: w72-76.

44. Motlagh AM, Bhunia AK, Szostek F, Hansen TR, Johnson MC, Ray B: Nucleotide and amino acid sequence of pap-gene (pediocin $\mathrm{AcH}$ production) in Pediococcus acidilactici H. Lett Appl Microbiol 1992, 15:45-48.

45. Nieto Lozano JC, Meyer JN, Sletten K, Pelaz C, Nes IF: Purification and amino acid sequence of a bacteriocin produced by Pediococcus acidilactici. J Gen Microbiol 1992, 138:1985-1990.

46. Le Marrec C, Hyronimus B, Bressollier P, Verneuil B, Urdaci MC: Biochemical and genetic characterization of coagulin, a new antilisterial bacteriocin in the pediocin family of bacteriocins, produced by Bacillus coagulans I (4). Appl Environ Microbiol 2000, 66:5213-5220.

47. Van Reenen CA, Chikindas ML, Van Zyl WH, Dicks LM: Characterization and heterologous expression of a class Ila bacteriocin, plantaricin 423 from Lactobacillus plantarum 423, in Saccharomyces cerevisiae. Int J Food Microbiol 2003, 81:29-40.

48. Tichaczek PS, Vogel RF, Hammes WP: Cloning and sequencing of sakP encoding sakacin $\mathrm{P}$, the bacteriocin produced by Lactobacillus sake LTH 673. Microbiology 1994, 140:361-367.

49. Larsen AG, Vogensen FK, Josephsen J: Antimicrobial activity of lactic acid bacteria isolated from sourdoughs: purification and characterization of bavaricin A, a bacteriocin produced by Lactobacillus bavaricus MI401. J Appl Bacteriol 1993, 75:113-122.

50. Loch TP, Xu W, Fitzgerald SM, Faisal M: Isolation of a Carnobacterium maltaromaticum- like bacterium from systemically infected lake whitefish (Coregonus clupeaformis). FEMS Microbiol Lett 2008, 288:76-84

51. Kawamoto S, Shima J, Sato R, Eguchi T, Ohmomo S, Shibato J, Horikoshi N, Takeshita K, Sameshima T: Biochemical and genetic characterization of mundticin KS, an antilisterial peptide produced by Enterococcus mundtii NFRI 7393. Appl Environ Microbiol 2002, 68:3830-3840.

52. Farías ME, Farías RN, de Ruiz Holgado AP, Sesma F: Purification and Nterminal amino acid sequence of Enterocin CRL 35, a 'pediocin-like' bacteriocin produced by Enterococcus faecium CRL 35. Lett Appl Microbiol 1996, 22:417-419.

doi:10.1186/1471-2180-11-69

Cite this article as: Nicolas et al.: Production, purification, sequencing and activity spectra of mutacins D-123.1 and F-59.1. BMC Microbiology 2011 11:69.

\section{Submit your next manuscript to BioMed Central and take full advantage of:}

- Convenient online submission

- Thorough peer review

- No space constraints or color figure charges

- Immediate publication on acceptance

- Inclusion in PubMed, CAS, Scopus and Google Scholar

- Research which is freely available for redistribution

Submit your manuscript at www.biomedcentral.com/submit
C Biomed Central 